\title{
ENTREPRENEURIAL BEHAVIOR OF POLISH SOCIETY
}

\author{
Patrycja KOKOT-STĘPIEŃ \\ Częstochowa University of Technology; patrycja.kokot-stepien@wz.pcz.pl, ORCID: 0000-0001-7222-0369
}

Purpose: The aim of the paper is to analyse entrepreneurial behaviour of Polish society and level of entrepreneurship in Poland in the years 2014-2018.

Design/methodology/approach: The first part of the article is based on an analysis of literature on the issues discussed. Then, based on the GEM Reports, the various manifestations of entrepreneurship and its level in Poland in 2014-2018 was assessed.

Findings: The conducted research indicates that more and more Poles see business opportunities in their environment and do not feel fear of failure. On the other hand, fewer people plan to set up their own business, which is undoubtedly the reflection of a good situation in the labour market, which allows people to freely choose between their own business and labour for hire, which, in turn, affects a decline in entrepreneurial intentions. The better motivation structure of young entrepreneurs is also visible in Poland, as most people start their own business seeing it as an opportunity rather than necessity.

Originality/value: The analysis allows the identification of areas requiring changes. Therefore, it may constitute the basis for the government to take appropriate actions to increase the level and quality of entrepreneurial activity.

Keywords: entrepreneurship, GEM, Polish society.

Category of the paper: General review.

\section{Introduction}

Entrepreneurship is a multidimensional phenomenon, constantly evolving and arousing interest of numerous scientific disciplines. It is expressed by the mode of action, showing initiative, readiness to undertake new, risky ventures in order to succeed. It is also a certain attitude towards management, which contributes to exploiting opportunities using broadly understood resources.

In the literature, there are various concepts defining the determinants of entrepreneurship. In some, the most important ones are innate predispositions of humans, in turn, in others, the attention is drawn to the environment in which they operate, their cognitive abilities and the ability to gain knowledge and experience. 
Entrepreneurship cannot be regarded as a single phenomenon but as the process with its beginning and subsequent stages. An attempt to systematize the course of the entrepreneurial process is not easy, though, due to the fact that it is variable, dynamic and initiated by the will of an individual. It depends on numerous factors and is very sensitive to the change in their level. Initially, it is undoubtedly essential to identify and grasp emerging opportunities, which leads to the establishment of a new venture in subsequent stages.

The objective of the article is to assess selected entrepreneurial behaviours of Polish society. In particular, the attitudes and entrepreneurial activities of Poles as well as the reasons for setting up a business in Poland, based on simple statistical methods, were analysed in the study. The data of the Global Entrepreneurship Monitor reports for the years 2014-2018 were used in the study, which allowed the assessment of trends in fluctuations in the tested indicators in time.

\section{The essence of entrepreneurship}

In the most general terms, entrepreneurship is the process of planning, organizing and conducting a business activity and taking the related risk. The person involved in the operations defined as entrepreneurship is known as an entrepreneur (Griffin, 2007). However, due to the lack of one precise definition of entrepreneurship in the literature, it is often presented not directly but in a descriptive way. It is sometimes perceived as an active process or a result of an action, another time, as an immanent characteristic of economic activities. Therefore, entrepreneurship is most frequently understood as (Czaja, 2014):

- the activity of small business sector and slightly larger enterprises forming the SME sector (the so called object definition) or human activities (the so called subject definition describing the person being the driving force of the operation);

- the characteristic of human activity (the so called attribute definition);

- the activity (also operation, process), which is subjected to systematic work on the establishment, development and strengthening of the position of own company (the so called functional or process definition).

In terms of the first approach, entrepreneurship is considered as a result of actions taken by entrepreneurs classified as the sector of small and medium enterprises or as a result of human activities undertaken in the market to satisfy their own needs and improve the comfort of life (Czaja, 2014). In terms of attributes, entrepreneurship is defined using a set of characteristics making up the so called entrepreneurial personality, enabling taking such actions which will allow entrepreneurs to achieve the intended goal. In turn, the perception of entrepreneurship as a process means creating and shaping something new, a set of consecutive actions that lead to the formation of market impact. The key categories occurring in this approach include: 
the ability to implement innovation, the ability to operate in the conditions of uncertainty and also the perception and seizure of opportunities emerging in the environment (Ropegga, 2016).

The essence of entrepreneurship is taking actions facilitating solving any problems and providing benefits to the specific organization through searching for and taking advantage of opportunities emerging in the environment. They can be associated with establishing a new venture, launching new products into the market or even entering into interesting business contracts. The scale of entrepreneurship in Poland is still growing, as evidenced by the number of new entities, particularly from the SME sector (Kempa, 2017).

\section{The specificity of the GEM study}

GEM is a reliable research project in the field of entrepreneurship focusing on entrepreneurial activities in early stages. It was established in 1997 under the partnership between London Business School and Babson College. The first research was conducted in 1999 in which 10 countries took part. In 2018 the research was carried out for the twentieth time and included 49 economies.

GEM provides a comprehensive set of indicators on entrepreneurship, allowing for the construction of detailed profiles of entrepreneurship in each economy studied. GEM's Adult Population Survey captures both informal and formal activity, moving beyond a reliance on business registrations which explain only a small proportion of entrepreneurship in many societies (GEM, 2018).

According to the assumption of the GEM report, entrepreneurship must be understood as every attempt to set up a new company or a new venture, such as self-employment, a new economic organization, the expansion of an existing organization, made by an individual, a group of people or an existing organization. The concept of a business activity is relatively broadly understood, which results in the measurement of the level of entrepreneurship, which includes both entrepreneurial behaviour leading to the creation of new companies and entrepreneurial behaviour of the already existing ones.

In GEM, it is important to indicate the stage in which the business venture is, although the analysis also includes the stages prior to the formal beginning of its implementation. It should be noted, however, that the study is aimed at the early stages of the operation. GEM uses three stages of development of the business venture. Depending on the stage in which the entrepreneur is, they are defined as nascent entrepreneurship, new business ownership or established business ownership. 


\section{Entrepreneurial attitudes of Poles in the years 2014-2018}

In the GEM study, the following four indicators are used to assess entrepreneurial attitudes: entrepreneurial intentions, recognizing business opportunities, entrepreneurial skills and fear of failure. The attitudes and perception of entrepreneurship in Poland in the years 2014-2018 are presented in Figure 1.

The presented data indicate that, in the research period assumed in the article, the number of people planning to set up business activities in the perspective of the next 3 years went down. In the first analysed year nearly $16 \%$ of Poles declared the willingness to work "on their own", in the subsequent two years every fifth respondent would rather run their own company than work full-time but in the years 2017-2018 only 1 in 10 Poles intended to become an entrepreneur and get involved in conducting their own business. It is worth pinpointing that, due to a wider range of wage labour, entrepreneurial intentions decline along with an increase in the economic development of the country. The lower propensity to set up a business in Poland, observed in the last two years of the research period, undoubtedly stems from the situation in the labour market which is improving in the last few years. Moreover, the financial uncertainty associated with running own business causes that some people, in spite of willingness they express, do not start working on their own.

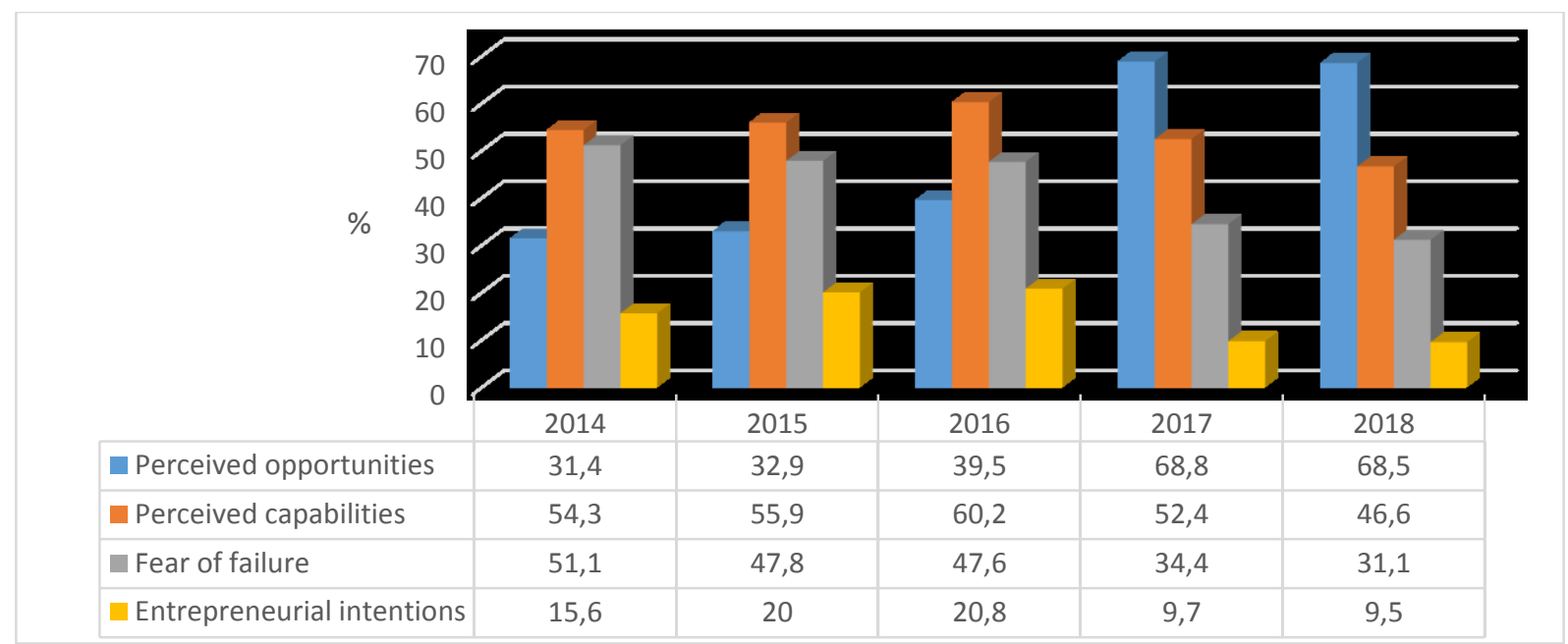

Figure 1. Entrepreneurial attitudes of Poles in the years 2014-2018. Own study based on: "Global Entrepreneurship Monitor".

The entrepreneurial process begins, however, with recognizing a business opportunity and the willingness to use it. In Poland, the indicator measuring the share of people who believe that, in the next six months, there will be the conditions favourable for setting up a business in their environment steadily increased until 2017. Initially, the growth rate was low since it amounted to 5\% in 2015 but already in 2017 the value of the analysed measure increased by as much as $74 \%$ compared to the previous year and it amounted to nearly $69 \%$. Therefore, this means that 7 in 10 Poles discerned the conditions in their environment good enough to start their own business. In the last year covered by the research the level of the indicator stabilized 
and remained at the same level as in the previous year. The high value of the analysed measure in the last two years of the research period may result from increasingly better perception of the local market as a place favourable for the emergence of new business ventures.

Recognizing the possible business opportunity is followed by the self-verification of knowledge and skills. Prospective entrepreneurs wonder too often whether their competence and experience allow for exploiting the emerging opportunity and succeeding in business. The presented data indicate that the percentage of people positively assessing their entrepreneurial skills steadily increased by 2016. However, in 2017 the trend reversed, which caused that the share of people considering their knowledge and skills as sufficient to run a business activity decreased by nearly 8 percentage points compared to the previous year, when the level was the highest and exceeded $60 \%$. In the last year covered by the research Poles believed in their own abilities even less since already only $46.6 \%$ of people assessed their knowledge and skills as sufficient to conduct a business.

An important factor reducing the level of entrepreneurship is the fear of failure. Many people, in spite of recognizing an opportunity in their environment and the willingness to seize it and the positive self-assessment of own abilities resign from starting their own business just due to the fear of failure. It should be emphasized, however, that the share of people who do not decide on exploiting a business opportunity due to the possible failure declined with each passing year. The data listed in the figure indicate that, in the whole analysed period, the percentage of people who fear failure fell by nearly half, which resulted in the fact that in 2018 already slightly over $31 \%$ of adults recognizing opportunities in their environment did not decide to set up a business for that reason.

It is worth noting that, in the analysed period, there was a significant change in entrepreneurial attitudes, particularly in the case of women. Most of all, an increasing number of both women and men recognize opportunities for conducting their own business activities in their environment, although it should be pinpointed that the growth rate for the group of women is slightly higher. On the other hand, fewer and fewer women and men feel the fear of possible failure in business, however, a greater decline applies to women whose entrepreneurship has been undoubtedly rising in recent years.

\section{Entrepreneurial activities of Poles}

According to the GEM model, the result of the attitudes and perception of entrepreneurship is the decision to start a business activity and make all efforts to establish the company. After 3 months of conducting a business activity, entrepreneurs pass to the subsequent stage new enterprises, which ends when the company operates in the market for 3.5 years. Entrepreneurs from the first two stages of the company's operation are included in the key GEM 
indicator - Total [early-stage] Entrepreneurial Activity (TEA), i.e. the people who are in the course of setting up a company and conducting a business activity for no longer than 3.5 years.

Depending on the stage of the company's development, under the GEM study, four forms of entrepreneurship can be indicated (GEM, 2018):

1. Nascent Entrepreneurship Rate - individuals who are currently nascent entrepreneurs, i.e., actively involved in setting up a business they will own or co-own; this business has not paid salaries, wages, or any other payments to the owners for more than three months.

2. New Business Ownership Rate - individuals who are currently owner-manager of a new business, i.e., owning and managing a running business that has paid salaries, wages, or any other payments to the owners for more than three months, but not more than 42 months.

3. Established Business Ownership Rate - individuals who are currently owner-manager of an established business, i.e., owning and managing a running business that has paid salaries, wages, or any other payments to the owners for more than 42 months.

4. Discontinuation of businesses - Business Discontinuance - individuals who have discontinued a business in the past 12 months, either by selling, shutting down, or otherwise discontinuing an owner/management relationship with the business.

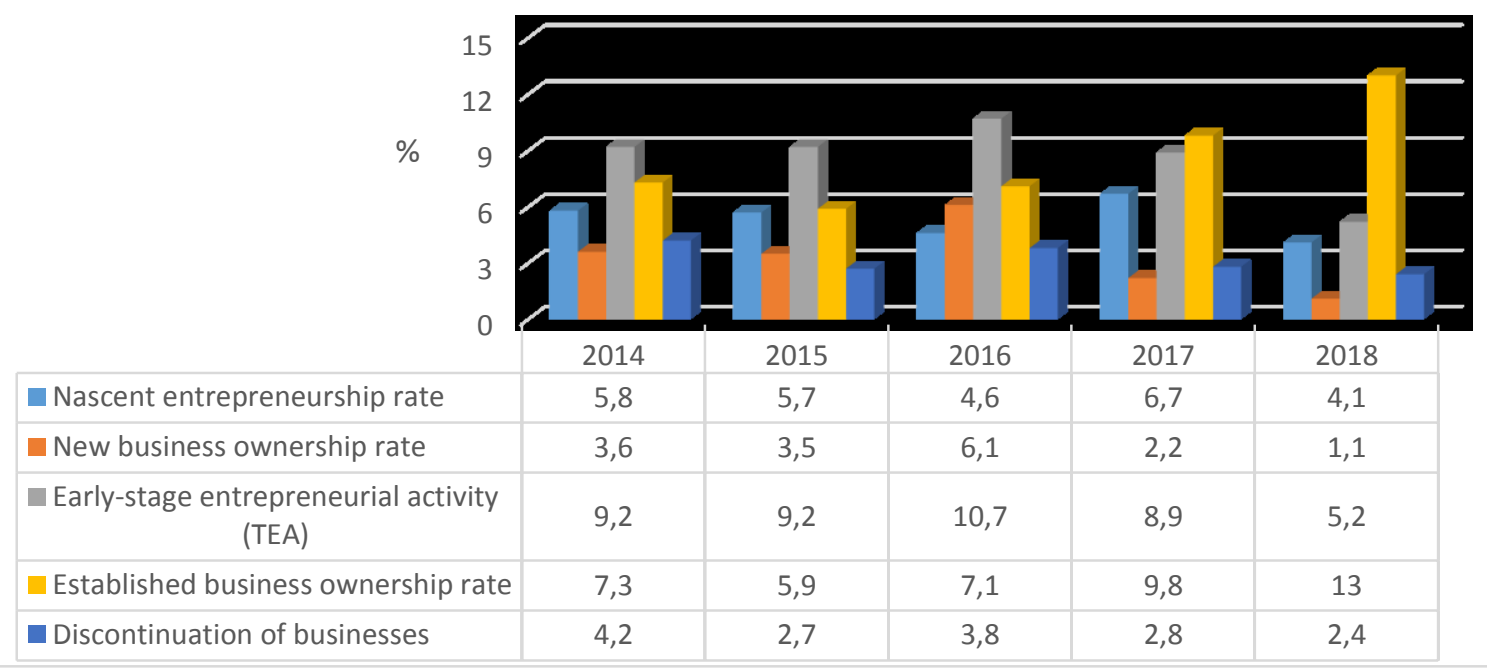

Figure 2. The level of entrepreneurial activity of Poles in years 2014-2018. Own study based on: "Global Entrepreneurship Monitor".

Figure 2 indicates that the most intense activity in terms of creating new companies (pre-entrepreneur) occurred in 2017, when $6.7 \%$ of Poles devoted their time and resources in order to set up a business. However, already in the following year the indicator fell by 2.6 percentage points, reaching the lowest level when taking into account all the years of the research period. This may be due to the improvement in the situation in the labour market, the decline in unemployment and the related better opportunity to find a satisfactory full-time job. At the same time, starting from 2017 there was a steady decline in the share of people who gave up conducting a business activity so that in 2018 their level was the lowest and amounted 
to $2.4 \%$. It is worth noting that the most frequent reasons for going out of business by Poles were: unprofitability, personal reasons and another opportunity.

After a relatively constant level of a number of new companies in the years 2014-2015 and an increase in the following year, as previously, the percentage of Poles setting up and conducting their companies up to 3.5 years decreased from 2017. Undoubtedly, this is due to the fact that, in this period, the share of people staring a business activity declined and thus fewer companies passed to the subsequent stage operating as nascent entrepreneurs. The fall within the first two stages of entrepreneurship had negative impact on the level of the TEA indicator which in the years 2014-2017 was around 9\% and in the last year covered by the research went down to only $5.2 \%$. This phenomenon can be the result of the improving situation in the labour market, delayed in time, since in the period of the low level of unemployment there is a decrease in the interest in setting up own business, which is accompanied by an undoubtedly higher risk than in the case of wage labour. In turn, there is a positive trend in the percentage of mature companies, which steadily increased starting from 2016 and eventually achieving the level of $13 \%$ in 2018. An increasing number of mature companies may indicate an increasing quality of enterprises which, in spite of constantly growing competition, are able to stay in the market.

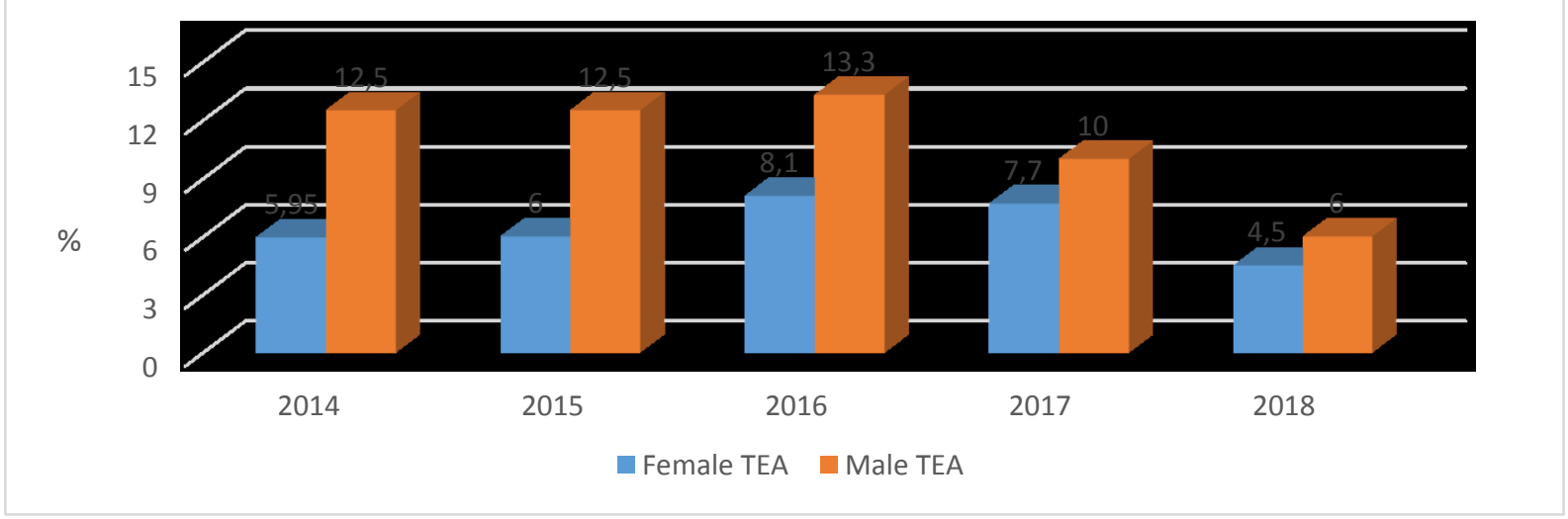

Figure 3. The level of entrepreneurial activities among women and men. Own study based on: "Global Entrepreneurship Monitor".

Throughout the analysed period men are business owners more often than women, however, year by year this difference decreases (figure 3). Whereas in the first year covered by the analysis $12.5 \%$ of men and nearly $6 \%$ of women started and ran business activities, in 2018 the percentage of indications respectively amounted to 6 and $4.5 \%$. Unfortunately, starting from 2016 , one may observe a steady decline in the level of young entrepreneurship (TEA) in the case of representatives of both sexes. This particularly applies to men in the case of whom the share declined from $13.3 \%$ to only $6 \%$.

The data presented in Table 1 indicate that the gender gap, measured as the difference between the percentage of men and women running young companies, decreases year by year. In the first year covered by the research it amounted to $6.6 \%$, and after the decline by 5.1 percentage points in the last year it was at the level of only $1.5 \%$. This is undoubtedly due 
to the decreasing share of men running companies at an early stage with a simultaneous increase in the number of mature companies run by them as well as an increase in the number of enterprises set up by women who more and more often, while not accepting remuneration lower than men, begin to develop professionally as company owners.

Table 1.

Gender gap in the case of young companies

\begin{tabular}{|c|c|c|c|c|c|}
\hline & $\mathbf{2 0 1 4}$ & $\mathbf{2 0 1 5}$ & $\mathbf{2 0 1 6}$ & $\mathbf{2 0 1 7}$ & $\mathbf{2 0 1 8}$ \\
\hline TEA - gender gap & $6,6 \%$ & $6,5 \%$ & $5,2 \%$ & $2,3 \%$ & $1,5 \%$ \\
\hline
\end{tabular}

Own study based on: "Global Entrepreneurship Monitor".

\section{The reasons for setting up companies in Poland}

In order to understand the nature of entrepreneurship it is important to recognize the motivation people are driven by while deciding on starting a business activity. The research included extreme motivation, i.e. using a business opportunity and entrepreneurship out of necessity. People motivated positively to conducting their own business can see an opportunity for self-fulfilment, achieving independence, recognition or just higher income. On the other hand, negative motivation means the necessity to start a business in the situation of unemployment or qualifications insufficient to gain the expected employment.

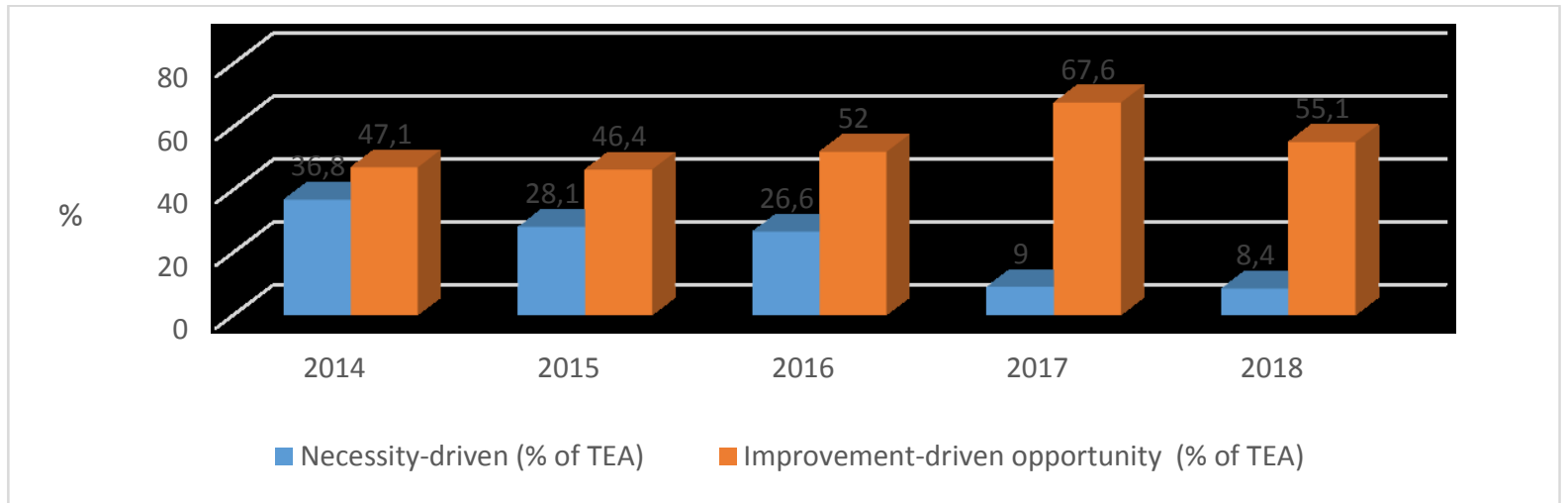

Figure 4. The structure of motivation to set up and conduct a business. Own study based on: "Global Entrepreneurship Monitor".

According to the data presented in Figure 4, throughout the analysed period, the dominant reason inducing Poles to become involved in their own business was the willingness to exploit an opportunity provided by running a company. In the first analysed year nearly $37 \%$ of entrepreneurs conducting a business for no longer than 3.5 years decided on its establishment out of necessity due to the lack of an opportunity for employment in the labour market, whereas $47 \%$ made such a decision since they identified an opportunity to improve the standard of living. In subsequent years, the positive motivation strengthened with a simultaneous decrease in the share of young companies established out of necessity. As a result of these changes, in 2017 
nearly $68 \%$ of people set up a company out of the desire to use an opportunity for achieving independence or increasing income whereas only $9 \%$ did this under compulsion. In spite of the fact that, in the subsequent year, the share of enterprises founded by people motivated positively decreased by 12.5 percentage points, still the advantage of the desire to seize an opportunity to improve the standard of living over the necessity of setting up a business is significant. It should be recalled that in the last year, as a result of the observed improvement in the labour market, which increasingly satisfies the needs of people searching for employment, the number of people who are ready to take risk while conducting their own business increases.

Table 2.

Motivation of women and men for setting up a business activity

\begin{tabular}{|c|c|c|c|}
\hline YEAR & GENDER & IMPROVEMENT-DRIVEN OPPORTUNITY & NECESSITY-DRIVEN \\
\hline \multirow{2}{*}{2014} & female & 58.8 & 38.1 \\
\cline { 2 - 4 } & male & 59.3 & 36.1 \\
\hline \multirow{2}{*}{2015} & female & 63.5 & 31.6 \\
\cline { 2 - 4 } & male & 72.1 & 26.3 \\
\hline \multirow{2}{*}{2016} & female & 66.7 & 31.8 \\
\cline { 2 - 4 } & male & 73.8 & 23.4 \\
\hline \multirow{2}{*}{2017} & female & 90.7 & 8.3 \\
\cline { 2 - 4 } & male & 89.8 & 8.3 \\
\hline \multirow{2}{*}{2018} & female & 95 & 5 \\
\cline { 2 - 4 } & male & 87.9 & 10.8 \\
\hline
\end{tabular}

Own study based on: "Global Entrepreneurship Monitor".

In the first three years covered by the analysis the percentage of women deciding on establishing a company out of necessity was higher than in the case of men. In turn, it was lower for those beginning their activity due to an opportunity provided by conducting own business (figure 5). However, in the next two years this situation changed with the result that in 2018 as much as $95 \%$ of women made a decision on setting up a company because of the desire to use opportunities arising from its conduct. On the other hand, the share of men motivated positively amounted to $88 \%$. Moreover, compared to men, fewer women decided to start their own business out of necessity.

\section{Conclusions}

Entrepreneurship distinguished by the ability to cope with all conditions is generally the process consisting in creating or recognizing opportunities for success and exploiting them. It is expressed by the activity, the identification of new opportunities, the ability to implement ideas as well as the propensity to take risk.

The research indicates that entrepreneurship in Poland is increasingly popular. In the analysed period, the share of people perceiving their environment as favourable for setting up a company increased. Moreover, in the last year it was women that recognized 
business opportunities more often than men. More importantly, year after year Poles are more willing to take risk since the percentage of people who fear failure is decreasing and now only every third Pole who has an opportunity to conduct a business activity does not take a decision on taking this step due to the fear of failure. In spite of the fact that, in recent years, Poles have assessed their business qualifications slightly worse, nearly half of them still evaluate their preparation for the role of an entrepreneur well. However, in connection with the improvement in the situation in the labour market observed recently as well as an increase in employment opportunities, the number of people thinking about their own company is decreasing. This is reflected in the level of the key GEM indicator - TEA, which achieved the lowest level in the last year covered by the analysis. It is also noteworthy that, among people running young enterprises, there are many more which are at the stage of setting up a business since there is 1 new company per 4 companies in the course of organization, i.e. operating for more than 3 but less than 42 months. However, the dominant group among those involved in entrepreneurship are mature enterprises, operating for more than 3.5 years whose competitive position is so strong that they are still able to stay in the market. It is also worth emphasizing that the structure of the motivation of Poles to set up own business is really favourable since far more people establish their own business activity due to the willingness to seize an opportunity to improve the standard of living rather than out of necessity. It is important since people motivated positively are more often oriented to development by means of which they act as entrepreneurs longer.

\section{References}

1. Bosma, N., and Kelley, D. (2018/2019). GEM - 2018/2019 Global Report. Global Entrepreneurship Monitor. https://www.gemconsortium.org.

2. Czaja, I. (2014). Przedsięborczość. Zagadnienia ogólne. In: J. Targalski (Eds.), Przedsiębiorczość $i$ zarzadzaniem matym i średnim przedsiębiorstwem (pp. 17-47), Warszafa: Difin.

3. Griffin, R.W. (2007). Podstawy zarzadzania organizacjami. Wraszawa: PWN.

4. Herrington, M., and Kew, P. (2016/2017). GEM - 2016/2017 Global Report, Global Entrepreneurship Monitor. https://www.gemconsortium.org.

5. Kelley, D., Singer, S., and Herrington, M. (2015/2016). GEM - 2015/2016 Global Report, Global Entrepreneurship Monitor. https://www.gemconsortium.org.

6. Kempa, E. (2017). Innowacyjność jako przejaw przedsiębiorczości polskich podmiotów gospodarczych. Zeszysty Naukowe Politechniki Częstochowskiej, 28(2), pp. 27-36. doi: 10.17512/znpcz.2017.4.2.03. 
7. Ropęga, J. (2016). Przedsięborczość. Zagadnienia ogólne. In: R.Lisowka, and J. Ropęga (Eds.), Przedsiębiorczość i zarządzanie $w$ małej i średniej firmie. Teoria I praktyka (pp. 15-45). Łódź: Wydawnictwo Uniwersytetu Łódzkiego.

8. Singer, S., Amorós, J.E., and Moska, D. (2014). GEM - 2014 Global Report, Global Entrepreneurship Monitor. https://www.gemconsortium.org.

9. Singer, S., Harrington, M., and Menipaz, E. (2017/2018). GEM-2017/2018 Global Report, Global Entrepreneurship Monitor. https://www.gemconsortium.org.

10. What is game? Available online https://www.gemconsortium.org/, 01.06.2019. 